\title{
ADAPTIVE CAPACITY OF SAIDI SHEEP AND GOATS TO HEAT STRESS AND DIURNAL VARIATION UNDER THE HOT DRY CONDITIONS OF UPPER EGYPT
}

\author{
A.M. Aboul Naga*, M. Hayder, T.M. Abdel Khalek, G.F. Abozed, A.K. Saleh, T.H. Abdel \\ Sabour and M.H. El Shafie
}

Animal Production Research Institute (APRI), Agriculture Research Center, Egypt,
* Corresponding author E. Mail: adelmaboulnaga@ gmail.com,

\author{
Submitted April 29, 2021; Accepted July 1, 2021; Published 1/10/2021
}

\section{SUMMARY}

The present work investigates the adaptive capacity of the indigenous Saidi sheep and Saidi goats (109 and 80 animals, respectively) to the prevailing hot dry conditions of Upper Egypt. The environmental stressors were summer heat stress (SHS); exercise heat stress (EHS), animals walk for $7 \mathrm{~km}$ under solar radiation; the third stressor was winter cold stress (WCS) outdoor.

Exposing the animals to $S H S(T H I=103.2)$, raised significantly $(P \leq 0.05)$ the respiration rate $(R R)$ of Saidi sheep and goats by 206 and $230 \%$, respectively, with the incidence of deep breath. Rectal temperature (RT) and skin temperature (ST) significantly increased $(P \leq 0.05)$ with SHS. Carry on effect, continue up to 8 pm. Exposing Saidi sheep and goats to exercise heat stress (EHS) increased RT and ST by $1.9^{\circ} \mathrm{C}$ and $4.7^{\circ} \mathrm{C}$, for both species. Respiration rate, multiplied by more than 5 folds for both species. Changes in the $G V$, differ between the two species, it increased by 575\% in sheep and only by175\% in goats. Local Saidi sheep and goats responded to physical heat stress by vast accelerating their RR; however, Saidi sheep need to go further to deep breath to cope the extra stressors

Winter cold stress at 4 am $(T H I=51)$, reduced $R T$ of Saidi sheep and goats by 0.7 and $0.4^{\circ} C$, respectively; from that at its comfortable zone at $2 \mathrm{pm}(\mathrm{THI}=62)$. Skin temperature declined by 3.7 and $3.9^{\circ} \mathrm{C}$, with WCS. Changes in respiratory parameters with cold stress were limited, compared to that of the thermal ones.

\section{Keywords: Saidi sheep and goats, Upper Egypt, adaptation, heat stress, winter cold stress}

\section{INTRODUCTION}

Globally, expected climate changes (CC) in the coming years represent critical challenge to mankind; it is linked to the high risk of frequent incidence of extreme climatic events (Ornes, 2018). The effects of $\mathrm{CC}$ are likely to be more effective in the hot dry areas. Developing countries are more vulnerable to $\mathrm{CC}$, with its high reliance on natural resources, limited institutional and financial capacity, and high poverty levels (Thornton et al., 2009). In the context of the expected CC, strategies of livestock communities in the hot dry areas are based on the identification of heat-tolerant animals within their populations and to breed them, while getting rid of the low adapted ones.

Goats have numerous advantages that enable them to maintain their production under extreme climate conditions. Based on these advantages, Dracan and Silanikove (2017) concluded that goat breeding plays an important role among farm animals, in mitigating and adapting to climate change (CC) in harsh environments.

Upper Egypt is a hot-dry subtropical region, extended from Giza north to Sudan border in the south (latitudes: $22^{\circ}$ south to $29^{\circ}$ north). It is characterized by intensive solar radiation, very hot summer, cold winter nights, and scarce rainfall (15

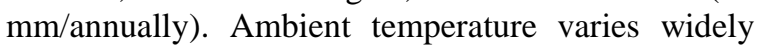

between day and night; diurnal variation often exceeds $20^{\circ} \mathrm{C}$. The prevailed agro- ecological conditions in Upper Egypt are intensive agriculture of more than a crop/year, and mix crop-livestock production system. Animal productions depend on cut and carry of the cultivated green fodder (mainly Egyptian clover in winter), and grazing crop residues in summer.

Saidi sheep and Saidi goat, are the indigenous Upper Egypt breeds. They are raised in small flocks; and are known for their tolerance to heat stress and the prevailed hot dry environment (Galal et al. 2005). Saidi sheep are considered the oldest Egyptian sheep breed in the country, they are characterized by high fertility, and high mortality rate of young animals (EL-Hommosi and Abdel-Hafiz, 1982; Guirgis, 1994and Elshazly and Youngs 2019). They are mostly dark in color, with open coarse fleece, some individuals are creamy or mixed colors. They have Roman noses, dewlap under the neck, length in tail and coarse wool cover (Ghanem 1980). Saidi goats are mostly black in color, small size, with small to medium ears, and are widely extended all over Upper Egypt (Galal et al., 2005) (Fig. 1).

The present study aims to investigate the adaptive capacity of the indigenous Saidi sheep and Saidi goats to the environmental conditions of Upper Egypt, which is very hot summer with frequent incidence of extreme hot waves, very cold winter 
nights with wide diurnal variation in ambient temperature. The thermo neutral zone of the Egyptian desert and non-desert goat breeds were reported by El-Sherbiny, et al. (1983) to range

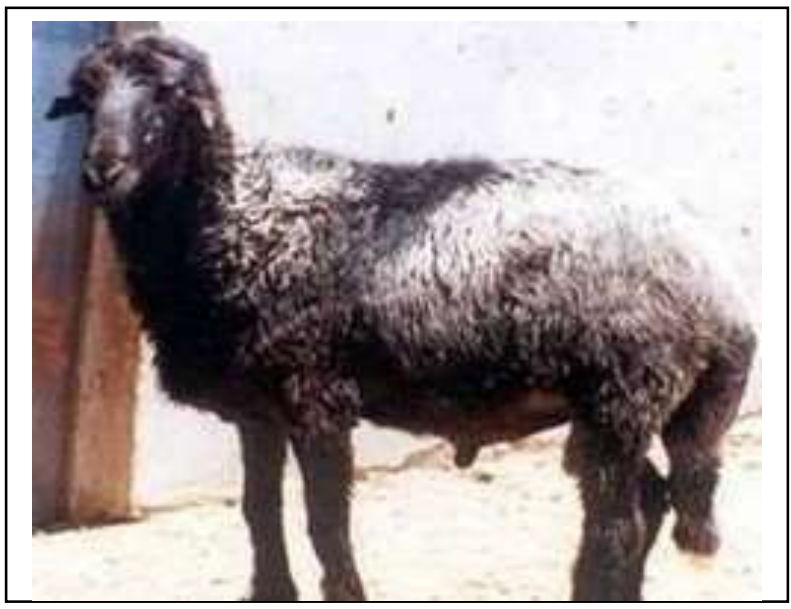

between 20 and $30^{\circ} \mathrm{C}$. While the upper critical temperature is above $35^{\circ} \mathrm{C}$ and the lower critical temperature is below $10^{\circ} \mathrm{C}$.

Fig. 1. Saidi ram and Saidi Buck.

\section{MATERIAL AND METHODS}

\section{Experimental design :}

The study was carried out at Malawi Experimental Farm, latitude $27^{\circ} \mathrm{N}$ and longitude $30^{\circ} \mathrm{E}, 50$ meters above sea level. Number of animals involved were 109 Saidi sheep and 80 Saidi goats (Table1). Three trials were carried out over 2018 and 2019 to investigate the adaptive capacity of Saidi sheep and Saidi goats to the environmental stressors in Upper Egypt. The animals were housed in semi open pens and fed concentrate mixture plus hay in

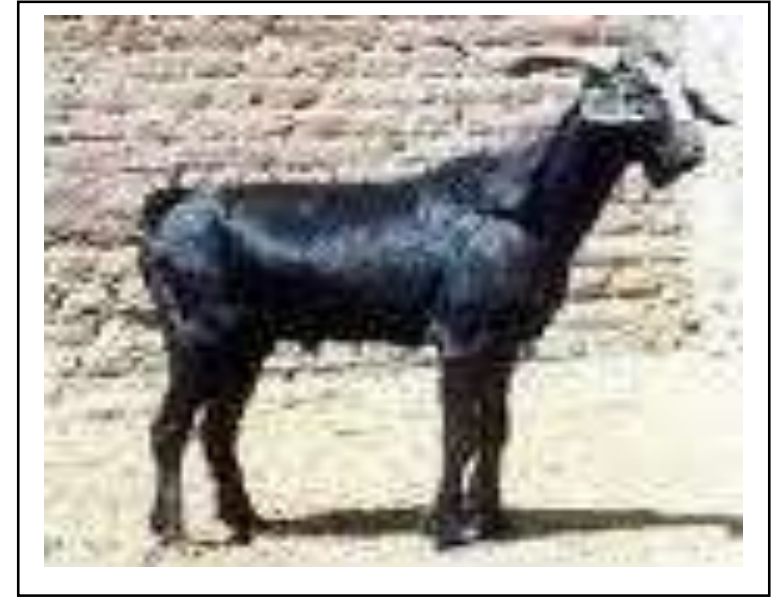

summer and Egyptian clover in winter. The applied treatments were as follow.

1-Summer heat stress (SHS) exposing the animals to direct solar radiation (SR) from $12 \mathrm{pm}$ to $2 \mathrm{pm}$ in August 2018.

2- Exercise heat stress (EHS) animals were encouraged to walk around $7 \mathrm{~km}$ under direct solar radiation from $12 \mathrm{pm}$ to $2 \mathrm{pm}$, simulating summer grazing on crop residues fields, August 2019.

3-Winter cold stress (WCS) animal kept outdoor at $4 \mathrm{am}$, compared with their performance at 2 and 8 pm, January 2018 and 2019.

Table 1. Number of animals involved in different trials and their average body weight (BW)

\begin{tabular}{lcccc}
\hline \multirow{2}{*}{ Trial } & \multicolumn{2}{c}{ Saidi sheep } & \multicolumn{2}{c}{ Saidi goats } \\
\cline { 2 - 5 } \multicolumn{1}{c}{ No. } & mean \pm SE & No. & mean \pm SE \\
\hline Summer Heat Stress 2018 (SHS) & 29 & $37.0 \pm 1.10$ & 20 & $27.0 \pm 1.10$ \\
Exercise Heat Stress Summer 2019 (EHS) & 30 & $32.5 \pm 0.73$ & 15 & $23.3 \pm 0.96$ \\
Winter Cold Stress 2018 (WCS) & 20 & $38.4 \pm 1.68$ & 20 & $27.0 \pm 1.10$ \\
Winter Cold Stress 2019 (WCS) & 30 & $37.9 \pm 0.89$ & 25 & $24.5 \pm 1.30$ \\
Total/average & 109 & $36.2 \pm 0.57$ & 80 & $25.2 \pm 0.58$ \\
\hline
\end{tabular}

\section{Studied traits:}

Physiological body parameters related to animal adaptation to environmental stressors, were measured on each animal before and after exposer to stress as follow:

-Rectal temperature (RT), as ${ }^{\circ} \mathrm{C}$ by clinical thermometer,

-Skin temperature (ST), as ${ }^{\circ} \mathrm{C}$ by infrared thermometer,

-Respiration rate (RR), as res./min., and

-Exhaled gas volume (GV), as 1/res. use open circuit technique, Harvard Apparatus, England; according to Yousef and Dill (1969)
Climatological parameters: dry- bulb temperature (TDB) and relative humidity (RH) were measured at rest and after exposure. Temperature Humidity Index (THI) were calculated after Hahn, et al. (2003): $\mathrm{THI}=((\mathrm{TDB} * 1.8)+32)-((0.55 *(\mathrm{RH} / 100))) *$

$\left.\left(\left(\mathrm{TDB}^{*} 1.8\right)+32\right)-58\right)$ and presented in Table (2). Animals are consider in its comfortable zone when THI value is $\leq 74$ in moderate stress when THI values ranged from 75-78under dangerous heat stress when THI is 79-83, and $\geq 84$ is under emergency heat stress. 
Table 2. Meteorological parameters at exposure in different trials

\begin{tabular}{lccccccccc}
\hline & \multicolumn{3}{c}{$\mathbf{A T}^{*}\left(\mathbf{0}^{\mathbf{0}}\right)$} & \multicolumn{3}{c}{ RH $(\boldsymbol{\%})$} & \multicolumn{2}{c}{ THI } \\
\cline { 2 - 10 } Year & $4 \mathrm{am}$ & $2 \mathrm{pm}$ & $8 \mathrm{pm}$ & $4 \mathrm{am}$ & $2 \mathrm{pm}$ & $8 \mathrm{pm}$ & $4 \mathrm{am}$ & $2 \mathrm{pm}$ & $8 \mathrm{pm}$ \\
\hline Summer 2018, (SHS) & 30.7 & 44.3 & -- & 71.3 & 29.0 & -- & 75.8 & 103.2 & 75.8 \\
Summer 2019, (EHS) & 23.7 & 45.5 & 28.5 & 80.7 & 22.7 & 53.8 & 67.3 & 107.2 & -- \\
Winter 2018, (WCS) & 9.1 & 17.6 & 8.1 & 70.7 & 48.9 & 74.0 & 52.0 & 62.0 & 51.2 \\
Winter 2019, (WCS) & 8.2 & 18.2 & -- & 85.0 & 51.2 & -- & 52.0 & 62.9 & -- \\
\hline
\end{tabular}

*AT: Ambient Temperature, RH: Relative Humidity, THI: Temperature- Humidity Index

\section{Statistical analysis:}

The model used for the statistical analysis was:

$\mathrm{Y}_{\mathrm{ijk}}=\mu+\mathrm{S}_{\mathrm{i}}+\mathrm{TD}_{\mathrm{j}}+(\mathrm{S} * \mathrm{TD})_{\mathrm{ij}}+\mathrm{e}_{\mathrm{ijk}}$ where,

$\mathrm{Y}_{\mathrm{ijk}}$ is the value of the studied parameter (RT, ST, RR and $\mathrm{GV}$ ),

$\mu$ is the overall mean,

$S_{i}$ is the fixed effect of $i^{\text {th }}$ species, $i=1$ and $2(1=$ sheep and $2=$ goats),

$\mathrm{TD}_{\mathrm{j}}$ is the fixed effect of $\mathrm{j}^{\text {th }}$ time of day, $\mathrm{j}=1,2,3(1=$ morning, 2=noon and $3=$ night),

$(\mathrm{S} * \mathrm{TD})_{\mathrm{ij}}$ is the interaction between species and time of day; and

$\mathrm{e}_{\mathrm{ijk}}$ is the random error distributed by $\left(0, \sigma_{e}^{2}\right)$

Two-way analysis of variance was applied for the model (SAS, 2009).

\section{RESULTS AND DISCUSSION}

\section{Summer heat stress (SHS):}

Estimates of THI under SHS, at 2 pm (Table 2), indicates that animals were under severe heat stress (THI=103.2). Exposing Saidi sheep to summer heat stress (SHS) under direct solar radiation (SR), at 2.0 $\mathrm{pm}$, raised significantly $(\mathrm{P} \leq 0.05)$ their thermal parameters (RT and ST), from their rest status at the morning (Table3). The carry-over effect of the heat stress on RT continues until $8 \mathrm{pm}$ at night, in spite of the reduction of the THI to 75.8. Mean while the effect of heat and SR on ST diminished per night and return close to their rest status in the morning (34.4 vs.33.9 ${ }^{0} \mathrm{C}$ ). Skin is an important pathway for heat exchange between the body and surrounding environments in the mammals (Rashamol et al., 2018).

The respiration rate (RR) showed the highest physiological changes in Saidi sheep when exposed to summer heat stress. Rate of change was $206 \%$ from that at rest, with wide individual variation (30$134 \mathrm{resp} . / \mathrm{min})$. Gas volume significantly increased $(\mathrm{P} \leq 0.05)$ from2.2at rest to $4.8 \mathrm{l} / \mathrm{min}$., under heat stress. They came back close to their rest status at 8 $\mathrm{pm}$. Accelerating respiration, seems to be the main mechanism of Saidi sheep to tolerate SHS. Similar finding was reported by Aboul Naga et al. (2011) for Barki desert sheep, under the hot dry conditions of Coastal Zone of Western Desert. Indu and Pareek (2015) reported that animals exposed to severe heat stress, resort respiratory evaporative cooling mechanisms through multiplying their RR by some folds.

For Saidi goats, thermal parameters (RT and ST) also showed significant changes $(\mathrm{P} \leq 0.05)$ with exposure to SHS; they were capable to return to their rest status by $8 \mathrm{pm}$ (Table 3 ). Exposing to severe heat stress resulted in hyperthermia of decreased thermal gradient between animals and surrounding environment, and therefor, heat loss becomes less effective (Indu and Pareek 2015). Respiration rate increased significantly with SHS by $230 \%$, ranged from 32-120 resp./min. Exhaled gas volume also significantly increased $(\mathrm{P} \leq 0.05)$ with heat stress, but with a narrower range than sheep (1.6 -3.3L/min.).

Table 3. Physiological body parameters of Saidi sheep and goats under summer heat stress

\begin{tabular}{|c|c|c|c|}
\hline \multirow[t]{2}{*}{ Parameter } & $\begin{array}{c}\text { At rest (7am) } \\
\mathrm{LSM} \pm \mathrm{SE}\end{array}$ & $\begin{array}{c}\text { Heat Stress (2pm) } \\
\text { LSM } \pm \text { SE }\end{array}$ & $\begin{array}{r}\text { At night }(8 p m) \\
\text { LSM } \pm \text { SE }\end{array}$ \\
\hline & \multicolumn{3}{|c|}{ Saidi sheep } \\
\hline $\mathrm{RT}\left({ }^{\circ} \mathrm{C}\right)$ & $39.1^{\mathrm{b}} \pm 0.06$ & $39.4^{\mathrm{a}} \pm 0.04$ & $39.5^{\mathrm{a}} \pm 0.05$ \\
\hline $\mathrm{ST}\left({ }^{\circ} \mathrm{C}\right)$ & $33.9^{c} \pm 0.14$ & $36.5^{\mathrm{a}} \pm 0.15$ & $34.4^{\mathrm{b}} \pm 0.10$ \\
\hline $\mathrm{RR}$ (resp./min) & $34.1^{\mathrm{b}} \pm 1.31$ & $70.2^{\mathrm{a}} \pm 5.10$ & $30.2^{\mathrm{b}} \pm 1.01$ \\
\hline GV (1/min) & $2.2^{b} \pm 0.52$ & $\begin{array}{l}4.8^{\mathrm{a}} \pm 0.79 \\
\text { Saidi goats }\end{array}$ & $2.4^{\mathrm{c}} \pm 0.27$ \\
\hline $\mathrm{RT}\left({ }^{\circ} \mathrm{C}\right)$ & $39.2^{b} \pm 0.07$ & $39.8^{\mathrm{a}} \pm 0.07$ & $39.3^{b} \pm 0.07$ \\
\hline $\mathrm{ST}\left({ }^{\circ} \mathrm{C}\right)$ & $34.9^{b} \pm 0.18$ & $36.9^{\mathrm{a}} \pm 0.06$ & $34.2^{\mathrm{c}} \pm 0.11$ \\
\hline $\mathrm{RR}$ (resp./min) & $20.8^{b} \pm 0.86$ & $47.8^{\mathrm{a}} \pm 4.56$ & $21.6^{\mathrm{b}} \pm 0.77$ \\
\hline $\mathrm{GV}(1 / \mathrm{min})$ & $1.6^{b} \pm 0.11$ & $3.3^{\mathrm{a}} \pm 0.23$ & $1.89^{c} \pm 0.05$ \\
\hline
\end{tabular}

*Within the same parameter, means followed by the same symbol don't differ significantly at 5\%probability

RT: rectal temperature; ST: skin temperature; RR: respiration rate; GV: gas volume

Inter-species variation was highly significant $(\mathrm{P} \leq 0.01)$ for $\mathrm{RR}, \mathrm{GV}$ and $\mathrm{ST}$, and significant $(\mathrm{P} \leq 0.05)$, for RT (Table 4). These are most probably due to different body sizes between the two species.
Saidi sheep weighed in average $36.2 \mathrm{~kg}$ while Saidi goats weighed $25.2 \mathrm{~kg}$ (Table 1). With the different responses of the two species to SHS, species by time interaction was highly significant $(\mathrm{P} \leq 0.01)$ for $\mathrm{RT}$, 
ST and GV, but not for RR. Seixas et al. (2017) reported that the smaller size animals are more heat tolerant. Pacifici et al. (2017) stated that small body size is a mean of adaptation to warmer climate.

Table 4. Mean squares (MS) for changes in physiological parameters of Saidi sheep and goats with Summer Heat Stress

\begin{tabular}{lccccc}
\hline \multirow{2}{*}{ Source of variation } & \multirow{2}{*}{ df } & \multicolumn{4}{c}{ MS } \\
\cline { 2 - 6 } & & RT & ST & RR & GV \\
\hline Species & 1 & $0.45^{*}$ & $5.6^{* *}$ & $7789.6^{* *}$ & $27.8^{* *}$ \\
Time & 2 & $6.12^{* *}$ & $87.37^{* *}$ & $16529.7^{* *}$ & $111.1^{* *}$ \\
Species*time & 2 & $1.95^{* *}$ & $3.77^{* *}$ & 585.2 & $3.4^{* *}$ \\
Residual & 141 & 0.08 & 0.44 & 225.9 & 0.46 \\
\hline
\end{tabular}

*Significant at $5 \%, * *$ significant at $1 \%$.

RT: rectal temperature; ST: skin temperature; RR: respiration rate; GV: gas volume

\section{Exercise heat stress (EHS):}

When Saidi sheep and goats were exposed to physical exercise under summer heat stress, walking for $7 \mathrm{~km}$ under direct solar radiation from 12 to $2 \mathrm{pm}$ with $\mathrm{THI}=107.2$; RT and ST increased by $1.9^{\circ} \mathrm{C}$ and $4.7^{\circ} \mathrm{C}$, respectively, in both species (Table 5). Respiration rate increased by nearly five folds in both Saidi sheep and goats, when exposed to EHS. Meanwhile, changes in GV with EHS significantly differed between the two species $(\mathrm{P} \leq 0.01)$, being $575 \%$ in sheep and only $175 \%$ in goats. Saidi sheep and goats respond to physical stress under heat by vastly accelerating their respiration rate. However, Saidi sheep need to go further to deep breath to withstand the combined stressors of physical exercise, solar radiation, and heat .Kasa et al. (1995) found that 1 hour exercise for Saanen goats increased their RR by 6-folds from that at rest. Barki desert sheep responded to exercise heat stress under the hot dry conditions of the Coastal Zone of Western Desert, by accelerating their RR, together with the frequent incidence of deep breath (Aboul Naga et al. 2021). The thermoregulatory mechanisms of Barki goats to tolerate EHS were to increase their respiratory heat loss and reduce their heat production, reflecting species differences in their mechanism to cope with the physical heat stress under hot dry desert conditions.

Table 5. Physiological body parameters of Saidi sheep and goats with Exercise Heat Stress

\begin{tabular}{|c|c|c|c|}
\hline Parameter & $\begin{array}{c}\text { At rest(7am) } \\
L S M \pm S E\end{array}$ & $\begin{array}{c}\text { Heat stress (2 pm) } \\
L S M \pm S E\end{array}$ & $\begin{array}{l}\text { Changes } \\
\mathrm{LSM} \pm \mathrm{SE}\end{array}$ \\
\hline \multicolumn{4}{|c|}{ Saidi sheep } \\
\hline $\mathrm{RT}\left({ }^{\circ} \mathrm{C}\right)$ & $39.1^{\mathrm{a}} \pm 0.06$ & $41.0^{\mathrm{b}} \pm 0.06$ & $1.9 \pm 0.07$ \\
\hline $\mathrm{ST}\left({ }^{\circ} \mathrm{C}\right)$ & $31.7^{\mathrm{a}} \pm 0.18$ & $36.4^{\mathrm{b}} \pm 0.51$ & $4.7 \pm 0.91$ \\
\hline RR (resp. /min.) & $21.7^{\mathrm{a}} \pm 0.58$ & $126.9^{\mathrm{b}} \pm 5.53$ & $105.2 \pm 5.60$ \\
\hline GV (1/min.) & $1.2^{\mathrm{b}} \pm 0.07$ & $8.10^{\mathrm{b}} \pm 0.20$ & $6.9 \pm 0.19$ \\
\hline \multicolumn{4}{|c|}{ Saidi goats } \\
\hline $\mathrm{RT}\left({ }^{\circ} \mathrm{C}\right)$ & $38.6^{\mathrm{a}} \pm 0.08$ & $40.7^{\mathrm{b}} \pm 0.10$ & $1.9 \pm 0.15$ \\
\hline $\mathrm{ST}\left({ }^{\circ} \mathrm{C}\right)$ & $31.2^{\mathrm{a}} \pm 0.24$ & $35.9^{\mathrm{b}} \pm 0.25$ & $4.7 \pm 0.35$ \\
\hline $\mathrm{RR}$ (resp./min) & $20.3^{\mathrm{a}} \pm 0.85$ & $85.4^{\mathrm{b}} \pm 10.85$ & $65.1 \pm 11.08$ \\
\hline GV (1/min) & $0.8^{\mathrm{a}} \pm 0.04$ & $2.2^{\mathrm{b}} \pm 0.34$ & $1.4 \pm 0.34$ \\
\hline
\end{tabular}

*Within the same parameter, means followed by the same symbol don't differ significantly at $5 \%$ probability

RT: rectal temperature; ST: skin temperature; RR: respiration rate; GV: gas volume

Winter cold stress (WCS):

Winter cold stress at $4 \mathrm{am}(\mathrm{WCS})$ with $(\mathrm{THI}=52)$, significantly reduced RT of Saidi sheep by $0.7^{\circ} \mathrm{C}$ from that at its comfortable winter zone by $2 \mathrm{pm}(\mathrm{THI}=62)$ (Table 6). Indu and Pareek (2015) reported that with the low THI in winter, animals are unable to maintain their core body temperature and their RT decreases. Skin temperature of Saidi sheep detect ably declined with WCS at 4 am by $3.7^{\circ} \mathrm{Cfrom}$ its values at $2 \mathrm{pm}$; and by $0.9^{\circ} \mathrm{C}$ from its value at $8 \mathrm{pm}$. The open fleece of Saidi sheep seem not sufficient as isolator from winter cold stress. Changes in the respiratory parameters with cold WCS were limited, compared to the changes in the thermal parameters. Respiration rate of Saidi sheep was reduced by $13 \%$ per night. The exhaled gas volume was reduced by $22 \%$ at 4 am and return to normal by 8 pm. Kamur et al. (2018) reported that the RR, RT and ST of Malpura lambs significantly increased $(P \leq 0.05)$ at the winter morning from the afternoon. 
Table 6. Physiological parameters of Saidi sheep and Saidi goats under Winter Cold Stress

\begin{tabular}{lccc}
\hline Parameters & 4am (outdoor) & 2pm & 8 pm \\
LSM \pm SE & LSM \pm SE & LSE \\
\hline RT $\left({ }^{\circ} \mathrm{C}\right)+$ & $38.9^{\mathrm{b}} * \pm 0.05$ & Saidi sheep & $39.1^{\mathrm{b}} \pm 0.09$ \\
$\mathrm{ST}\left({ }^{\circ} \mathrm{C}\right)$ & $27.8^{\mathrm{b}} \pm 0.48$ & $39.6^{\mathrm{a}} \pm 0.09$ & $25.3^{\mathrm{c}} \pm 0.29$ \\
$\mathrm{RR}(\mathrm{resp} . / \mathrm{min})$ & $23.7^{\mathrm{b}} \pm 0.75$ & $33.5^{\mathrm{a}} \pm 0.72$ & $19.1^{\mathrm{c}} \pm 0.71$ \\
$\mathrm{GV}(\mathrm{l} / \mathrm{min})$ & $2.9^{\mathrm{b}} \pm 0.09$ & $31.5^{\mathrm{a}} \pm 1.89$ & $2.9^{\mathrm{b}} \pm 0.06$ \\
& & $3.7^{\mathrm{a}} \pm 0.15$ & \\
$\mathrm{RT}\left({ }^{\circ} \mathrm{C}\right)$ & $39.0^{\mathrm{b}} \pm 0.06$ & Saidi goats & $39.1^{\mathrm{b}} \pm 0.07$ \\
$\mathrm{ST}\left({ }^{\mathrm{o}} \mathrm{C}\right)$ & $26.2^{\mathrm{b}} \pm 0.37$ & $39.7^{\mathrm{a}} \pm 0.06$ & $25.2^{\mathrm{b}} \pm 0.29$ \\
RR $(\mathrm{resp} . / \mathrm{min})$ & $21.0^{\mathrm{b}} \pm 0.83$ & $32.9^{\mathrm{a}} \pm 0.75$ & $17.7^{\mathrm{b}} \pm 0.70$ \\
$\mathrm{GV}(\mathrm{l} / \mathrm{min})$ & $2.6^{\mathrm{b}} \pm 0.06$ & $26.8^{\mathrm{a}} \pm 1.86$ & $2.7^{\mathrm{b}} \pm 0.03$ \\
\hline
\end{tabular}

*Within the same parameter, means follow by the same symbol don't differ significantly at $5 \%$ probability

RT: rectal temperature; ST: skin temperature; RR: respiration rate; GV: gas volume

Changes in the physiological parameters of Saidi goats with WCS tend to be similar to that of Saidi sheep Species differences were only observed only in the magnitude of the effect, being less in Saidi goats than in sheep (Table 7). Species variation was significant $(\mathrm{P} \leq 0.05)$ for $\mathrm{RR}$ and $\mathrm{GV}$, and insignificant for RT, and species *time interaction. It seems that both species withstand well winter cold stress (THI around 50) and react well to the diurnal variation in ambient temperature between day and night up to $20^{\circ} \mathrm{C}$.

Table 7. Mean squares (MS) of changes in physiological parameters of Saidi sheep and goats with Winter Cold Stress

\begin{tabular}{lccccc}
\hline \multirow{2}{*}{ Source of variation } & \multirow{2}{*}{ df } & \multicolumn{3}{c}{ MS } \\
\cline { 3 - 6 } & & $\mathbf{R T}$ & $\mathbf{S T}$ & $\mathbf{R R}$ & $\mathbf{G V}$ \\
\hline Species & 1 & $1.05^{*}$ & 43.85 & $657.25^{* *}$ & $5.5^{* *}$ \\
Time & 2 & $11.47^{* *}$ & $1331.2^{* *}$ & $2047.2^{* *}$ & $17.29^{* *}$ \\
Species*time & 2 & 0.06 & 3.65 & 27.56 & 0.002 \\
Residual & 224 & 0.21 & 14.7 & 83.6 & 0.51 \\
\hline
\end{tabular}

*Significant at $5 \%, * *$ significant at $1 \%$.

RT: rectal temperature; ST: skin temperature; RR: respiration rate; GV :gas volume

\section{CONCLUSIONS}

Exposing Saidi sheep and goats to summer heat stress (SHS) significantly raised their physiological body parameters with the effect carry on up at $8 \mathrm{pm}$. When they were exposed to physical heat stress (EHS) under direct solar radiation, their thermal parameters sharply increased, and RR increased by nearly five folds. Saidi sheep need to go to deep breath to stand the environmental stressors such as heat, solar radiation and physical exercise. Saidi goats seems to stand the environmental stress of Upper Egypt; better than Saidi sheep. Both sheep and goats return to their normal physiological status at night.

Winter cold stress at 4 am reduced the thermal parameters of Saidi sheep and goats from its comfortable zone at $2 \mathrm{pm}$. Changes with WCS were mainly in the thermal parameters rather than the respiratory ones, in contrary to the heat stress, where the main adaptive mechanism was through the respiratory performance.

In Summary, Saidi sheep and goats adapt well to the severe hot- dry conditions of Upper Egypt, even with physical exercise, utilizing accelerating panting, with incidence of deep breath in sheep. They further with stand diurnal variation in ambient temperature of more than $20^{\circ} \mathrm{C}$, and cold winter stress that prevailed in Upper Egypt.

\section{REFERENCES}

Aboul-Naga, A.M., H.H. Khalifa, A.R. El-beltagy, T.M. Abdel-Khalek, M.H. Elshafie, M.M. Anwar, B. Rischkowsky, 2011. Tolerance to abiotic stresses in Egyptian Barki desert sheep and goats raised under hot-dry conditions: Individual variations. $10^{\text {th }}$ International Conference on Development of Dry lands, Meeting the Challenge of Sustainable Development in Dry lands under Changing Climate ,12 December 2010, Cairo, Egypt. Pp. 445-459.

Aboul-Naga; A.M., M.H. Elshafie, H. Khalifa, Mona Osman; T.M. Abdel Khalek, A.R. El-Beltagi, E.S. Abdel-Aal, T.H. Abdel-Sabour, M. Rekik, Mariem Touatbi; and Barbara Rischowesk, 2021. Tolerance of Desert Sheep and Goats to Exercise Heat Stress under Hot Dry Conditions, and its Correlation with their Production Performance. Small Ruminant Research (under publication).

Dracan, N.K. and N. Silanikove, 2017. The advantages of goats for future adaptation to Climate Change: A conceptual overview. Small Ruminant Research 163: 34-38. 
El- Hommosi F. F. and G. E. Abdel-Hafiz, 1982. Reproductive performance of Ossimi and Saidi sheep under two pre- pubertal planes of nutrition. Assiut Vet. Med. J., 10 (19): 61- 66.

Elshazly, A.G. and C.R. Youngs, 2019. Feasibility of utilizing advanced reproductive technologies for sheep breeding in Egypt. 1. Genetic and nutritional resources. Egyptian Journal of Sheep \& Goat Sciences, 14 (1): 39 - 52

El-Sherbiny, A.A., M.K. Yousef, M.H. Salem, H.H. Khalifa, H.M. Abd El-Bary and M.H. Khalil, 1983 .Thermoregulatory responses of a desert and a non-desert goats breeds. Al-Azhar Agr. Res.Bull., Faculty of Agriculture, Al-Azhar Univ.

Indu, S. and Pareek, A., 2015. A Review: Growth and Physiological Adaptability of Sheep to Heat Stress under Semi-Arid Environment. International Journal of Emerging Trends in Science and Technology. Vol. 02. Issue 09. Pages 3188-3198. http://dx.doi.org/10.18535/ijetst/v2i9.09.

Galal, S., Ferial Abdel-Rasoul; M.R. Anous and I. Shaat, 2005. On station characterization of small ruminant breeds in Egypt. In: (Iniguez, L.C.,Ed) Characterization of Small Ruminant Breeds in West Asia and North Africa, Vol. 2, International Center for Agricultural Research in the Dry Areas (ICARDA), Aleppo, Syria, pp: 141-193.

Ghanem, Y.S., 1980. (Ed.) Encyclopedia of Animal Wealth. Part I: Arab Sheep Breeds, Arab Organization for Education, Culture and Sciences, Arab Centre for the Studies of Arid and Dry Lands (in Arabic), Syria.

Guirgis, R.A., 1994. Egyptian Sheep Resources, in Animal Genetic Resources Information Bulletin13 edits by Boyazoglu, J., FAO (REUR) and Chupin, D., FAO (AGA) VialeDelleTerme di Caracalla, Rome, Italy

Hahn, G.L., T.L. Mader and R.A. Eigenberg, 2003. Perspective on development of thermal indices for animal studies and management. Symp. Proc.: Interactions between Climate and Animal Production. EAAP Technical Series No. 7. Wageningen Academic Publ., Netherlands, pp. 31-45.
Kasa I.W., M.K. Hill, C.J. Thwaites and N.D. Baillie, 1995. Physiological effects of exercise in male and female Saanen goats at the same body weight but different feed intake. Small Ruminant Research 16: 83-86

Kamur, K.D, A.K. Singh, A. Sahoo and S.M. Naqvi, 2018. Effect of altered ambient temperature through shelter modifications on physiological indicators of Malpura lambs reared in semi-arid region during winter. Journal of Thermal Biology 72: 161-167.

Ornes, S., 2018. Core concept: how does climate change influence extreme weather? Impact attribution research seeks answers. PNAS 115(33):8232-8235

Pacifici M.P., S.H. Visconti, J.E. Butchart, M. Watson, Cassola Francesca and C. Rondinini, 2017. Species' traits influenced their response to recent climate change. Nature Climate Change 7(3): 205-208.

Payne, W.J. and R.T. Wilson, 1999. An Introduction to Animal Husbandry in the Tropics, 5th Edition. Wiley-Blackwell. ISBN: 978-0-632-04193-0.

Rashamol V.P., V. Sejian, Bagath M.; G. Krishnan, P.R. Archana and R. Bhatta, 2018. Physiological adaptability of livestock to heat stress: an updated review. Journal Animal Behaviorand Biometeorology, 6:62-71.

SAS , 2009. SAS User's Guide: Statistics. SAS Inst. Inc., Cary, NC.,US

Seixas L, C. Melo, C. Tanure, V. Peripolli and C. McManus, 2017. Heat tolerance in Brazilian hair sheep. Asian-Australasian Journal of Animal Sciences 30 (4): 593-601.

Thornton, P.K., J. Van de Steeg, A. Notenbaert, and M. Herrero, 2009. The impacts of climate change on livestock and livestock systems in developing countries: A review of what we know and what we need to know. Agricultural Systems 101 (2009) 113-127.

Yousef, M.K. and D.B. Dill, 1969. resting energy metabolism and cardiore spiratory activity in the burro, Equus. Asinus. Journal of Applied Physiology, Vol. 27:229-232. 
القدره التكيفيه للأغنام والماعز الصعيدي للاجهاد الحراري والتغيرات البيئيه اليوميه للظروف الحاره الجافه بصعيد

عادل أبوالنجا، محمد حيدر، طارق عبد الخالق، جمال أبو زيد، أيمن صالح، طه عبد الصبور، عحم الثافعي معهز بحوث الاتتاج الحيواني، مركز البحوث النراعية، القاهرة، مصر

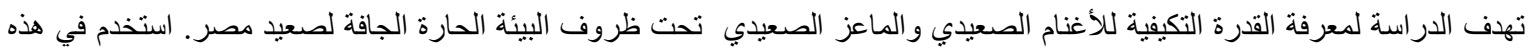

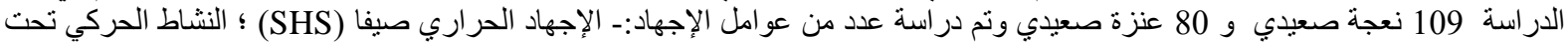

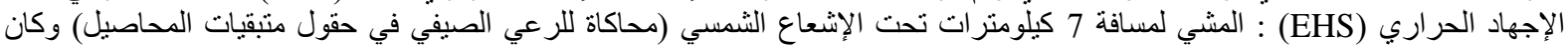

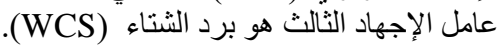

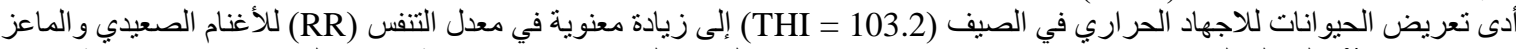

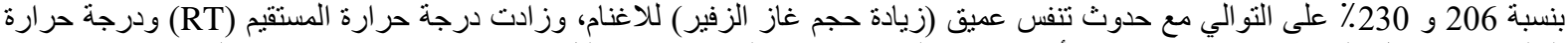

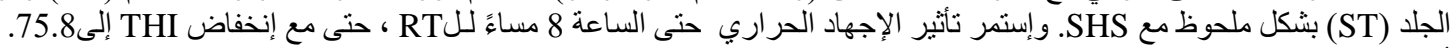

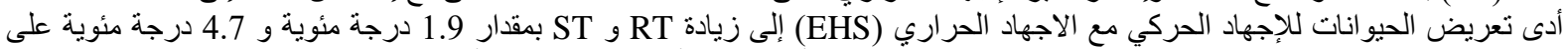

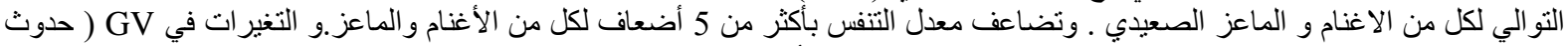

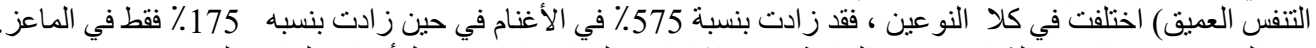

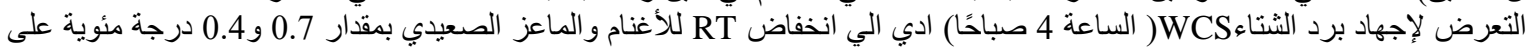

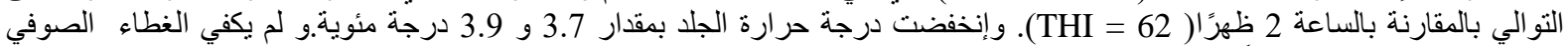

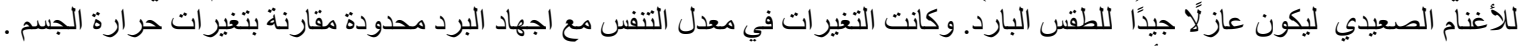

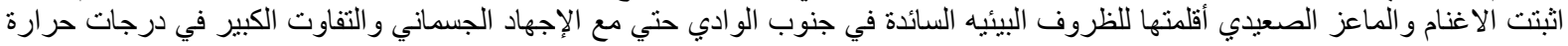
الليل و النهار و البرودة الثنديدة في ليالي الثتاء. 